\title{
A curious cause of pseudo-haematuria: a neglected vaginal pessary
}

\author{
Jorge Cabral Ribeiro, ${ }^{1}$ Carolina Leite ${ }^{2}$
}

'Department of Urology, Hospital de Braga, Braga, Portugal

${ }^{2}$ Department of Radiology, Hospital de Braga, Braga, Portugal

\section{Correspondence to} Dr Jorge Cabral Ribeiro, j.cabral.ribeiro@ hospitaldebraga.pt

Accepted 17 April 2017
CrossMark

To cite: Cabral Ribeiro J, Leite C. BMJ Case Rep Published Online First: [please include Day Month Year]. doi:10.1136/bcr-2017219690

\section{DESCRIPTION}

Vaginal pessaries represent a valid therapeutic option for the management of female pelvic organ prolapse in elderly women with significant comorbidities. Although leading to good functional and quality of life outcomes, when neglected, they can cause significant and severe complications.

An 87-year-old woman semidependent and uncooperative due to progressive Alzheimer's dementia, who has lived in a nursing home for the last 5 years, presented to our outpatient clinic for 'intermittent hematuria'. She carried a pelvic ultrasound documenting a 'polypoid formation with $23 \mathrm{~mm}$ on the posterior bladder wall suggesting a bladder tumour'.

The blood loss had been detected intermittently in the diaper that she uses for hygienic purposes.

There were no analytical abnormalities except for leucoerythrocyturia with positive Escherichia coli urine culture. The hypothesis of a urothelial lesion led to the scheduling of a cystoscopy under anaesthesia and an abdominopelvic CT scan.

The abdominopelvic CT scan documented 'a hyper dense linear formation, superior to the vaginal dome' (figure 1). After observing the images, we suspected an intravaginal foreign body and performed the coronal CT scan reconstruction. The hyperdense retrovesical formation corresponds to an intravaginal ring shaped structure, consistent with a pessary (figure 2).

We performed the cystoscopy under anaesthesia and saw a globally inflammatory bladder with a

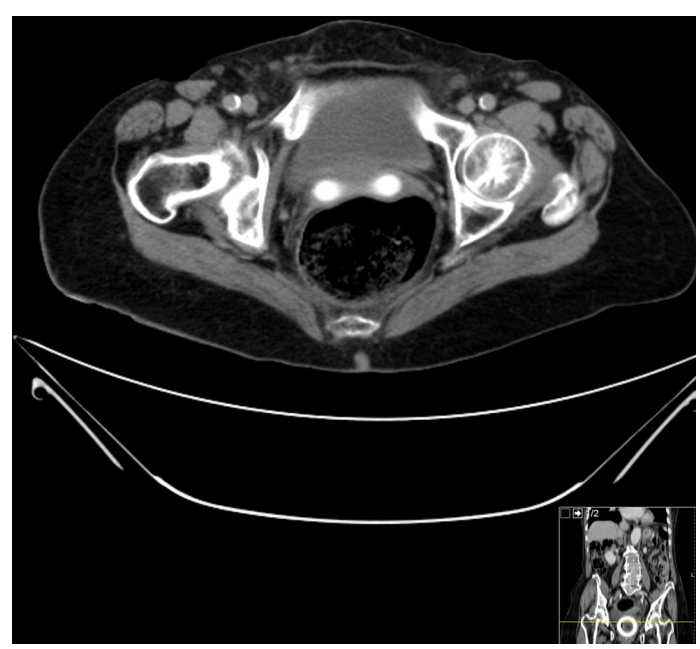

Figure 1 CT scan-within the pelvic cavity we observe a bladder with smooth and regular wall and in retrovesical position and next to the vaginal dome a hyperdense formation.

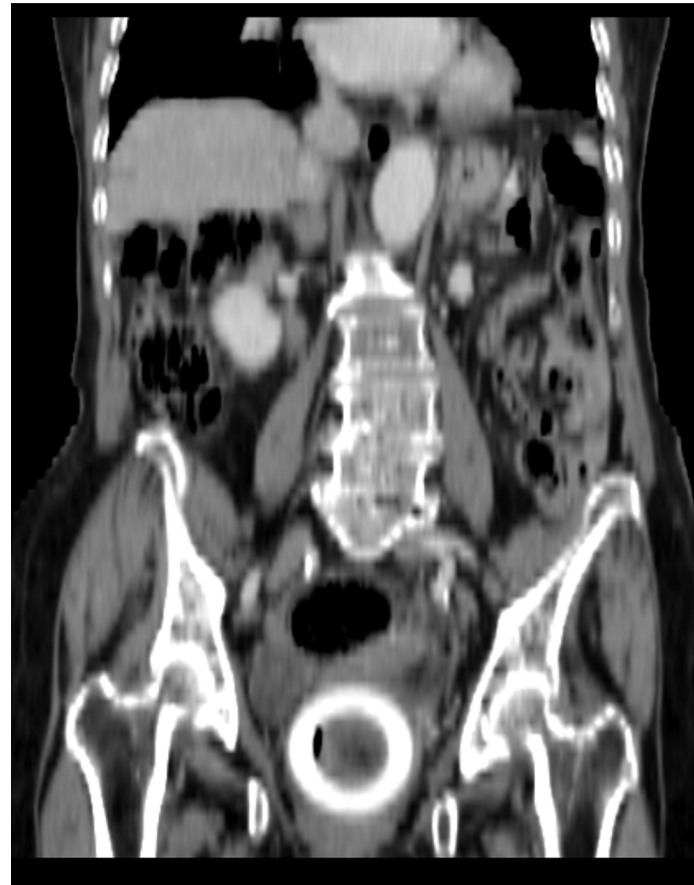

Figure 2 Coronal CT reconstruction-the hyperdense retrovesical formation corresponds to an intravaginal ring shaped structure consistent with a pessary.

bulbous pattern, but without tumour lesions. A bladder biopsy revealed erosive cystitis.

The procedure was completed with a vaginal examination that confirmed the presence of a pessary intimately adhering to the vaginal wall with an intense inflammatory reaction. Its removal triggered abundant vaginal bleeding.

\section{Learning points}

- This case report emphasises that in the setting of signs or symptoms of a genitourinary disorder, a meticulous physical and pelvic examination should always be performed before the request of any medical exams.

- Neglected medical devices can cause potentially severe complications, and lead to unnecessary appointments as well as invasive procedures, and carry high medical costs. ${ }^{1}$

- This case report highlights the indispensability of good medical registries within the personal clinical file, and reinforces the need for an electronic department registry that enables clinicians to accurately recall these patients. ${ }^{2}$ 
It was not possible to determine the date of placement of the neglected vaginal pessary. Neither the nursing home nor her family members had knowledge of the condition (no information on her individual file).

The patient is well, without macroscopic blood loss, although with persistent asymptomatic bacteriuria.

Contributors JCR was the attending urologist, the author of the manuscript, and collected and reviewed the data. CL performed the CT scan and review the manuscript.

Competing interests None declared.

Patient consent Consent obtained from guardian.
Provenance and peer review Not commissioned; externally peer reviewed.

(C) BMJ Publishing Group Ltd (unless otherwise stated in the text of the article) 2017. All rights reserved. No commercial use is permitted unless otherwise expressly granted.

\section{REFERENCES}

1 Arias BE, Ridgeway B, Barber MD. Complications of neglected vaginal pessaries: case presentation and literature review. Int Urogynecol I Pelvic Floor Dysfunct 2008;19:1173-8.

2 Lynch MF, Ghani KR, Frost I, et al. Preventing the forgotten ureteral stent: implementation of a web-based stent registry with automatic recall application. Urology 2007;70:423-6.

Copyright 2017 BMJ Publishing Group. All rights reserved. For permission to reuse any of this content visit http://group.bmj.com/group/rights-licensing/permissions.

BMJ Case Report Fellows may re-use this article for personal use and teaching without any further permission.

Become a Fellow of BMJ Case Reports today and you can:

- Submit as many cases as you like

- Enjoy fast sympathetic peer review and rapid publication of accepted articles

- Access all the published articles

- Re-use any of the published material for personal use and teaching without further permission

For information on Institutional Fellowships contact consortiasales@bmjgroup.com

Visit casereports.bmj.com for more articles like this and to become a Fellow 